\title{
Sedation with a remifentanil infusion to facilitate rapid awakening and tracheal extubation in an infant with a potentially compromised airway
}

This article was published in the following Dove Press journal:

Journal of Pain Research

27 October 2016

Number of times this article has been viewed

\author{
Jeffrey Naples ${ }^{1,2}$ \\ Mark W Hall ${ }^{1,2}$ \\ Joseph D Tobias 3,4 \\ 'Department of Pediatrics, The Ohio \\ State University, ${ }^{2}$ Division of Pediatric \\ Critical Care Medicine, Nationwide \\ Children's Hospital, ${ }^{3}$ Department of \\ Anesthesiology and Pain Medicine, \\ Nationwide Children's Hospital, \\ ${ }^{4}$ Department of Anesthesiology \\ and Pain Medicine, The Ohio State \\ University, Columbus, OH, USA
}

\begin{abstract}
Sedation is generally required during endotracheal intubation and mechanical ventilation in infants and children. While there are many options for the provision of sedation, the most commonly used agents such as midazolam and fentanyl demonstrate a context-sensitive half-life, which may result in a prolonged effect when these agents are discontinued following a continuous infusion. We present a 20 -month-old infant who required endotracheal intubation due to respiratory failure following seizures. At the referring hospital, multiple laryngoscopies were performed with the potential for airway trauma. To maximize rapid awakening and optimize respiratory function surrounding tracheal extubation, sedation was transitioned from fentanyl and midazolam to remifentanil for 18-24 hours prior to tracheal extubation. The unique pharmacokinetics of remifentanil are presented in this study, its use in this clinical scenario is discussed, and its potential applications in the pediatric intensive care unit setting are reviewed. Keywords: remifentanil, sedation, pediatric, airway, extubation
\end{abstract}

\section{Introduction}

Infants and children generally require sedation to alleviate pain and agitation during mechanical ventilation. ${ }^{1,2}$ In patients with a known or suspected difficult or critical airway, additional precautions may be needed when they are deemed ready for tracheal extubation. It is particularly important to ensure that tracheal extubation occurs at a time when the residual effects of sedation have abated to avoid any impact that these agents may have on upper airway control and respiratory function. Further, the avoidance of agitation with the potential for additional airway trauma during the awakening process is key in this setting. In the pediatric intensive care unit (PICU), midazolam, fentanyl, and morphine are commonly used to provide sedation and analgesia during endotracheal intubation and mechanical ventilation. Although generally effective, these agents demonstrate a context-sensitive half-life so that the duration of their effects may be lengthy following prolonged infusions. ${ }^{3,4}$ As such, following discontinuation of these medications, it is difficult to predict when the patient will be appropriately awake and alert for tracheal extubation. On the other hand, there is a risk of inadvertent tracheal extubation if sedation and analgesia are not adequate. We report a 20-monthold with a history of difficulties with endotracheal intubation at the referring hospital who required sedation during mechanical ventilation for 24-36 hours to allow for resolution of airway edema and coordination of services to allow for a controlled attempt at tracheal extubation. The ultrashort-acting synthetic opioid, remifentanil, was used to provide sedation and yet allow for rapid awakening without concerns of
Correspondence: Jeffrey $C$ Naples Department of Pediatrics, Nationwide Children's Hospital, 700 Children's Drive, Columbus, OH 43205, USA

Tel +l 6I4 7223436

Email Jeffrey.Naples@ nationwidechildrens.org 
a context-sensitive half-life. The basic pharmacokinetics of remifentanil are discussed, previous reports of its use of sedation during mechanical ventilation are reviewed, and clinical recommendations for its use in this scenario are presented.

\section{Case report}

Institutional review board approval as well as written informed consent is not required for individual case reports at Nationwide Children's Hospital (Columbus, OH, USA). A 20-month-old, $11 \mathrm{~kg}$ toddler with shunted congenital hydrocephalus and absent septum pellucidum presented with respiratory failure secondary to status epilepticus. The patient initially presented to a referring hospital where he was noted to have a difficult airway that required five attempts to achieve endotracheal intubation. Ultimately, his airway was secured with an uncuffed 4-0 mm endotracheal tube. The reasons for the multiple intubation attempts were unclear, as there were no reports of airway problems during prior anesthetic events for ventriculoperitoneal shunt placement during the neonatal period. On arrival, the patient's hemodynamic and respiratory status were stable. Physical examination was notable for moderate micrognathia. Sedation during mechanical ventilation was initiated with continuous infusions of fentanyl at 2 $\mu \mathrm{g} / \mathrm{kg} / \mathrm{h}$ and midazolam at $0.15 \mathrm{mg} / \mathrm{kg} / \mathrm{h}$. Following a 2-day PICU course, the patient's clinical status improved and he was deemed ready for tracheal extubation from respiratory and neurologic perspectives. However, even after a 24-hour course of dexamethasone for presumed airway edema, there was no air leak around the endotracheal tube at a peak inflating pressure of $30 \mathrm{~cm} \mathrm{H}_{2} \mathrm{O}$. The pediatric otorhinolaryngology (ear, nose, and throat) service was consulted to evaluate his airway and a decision was made to attempt tracheal extubation the next morning in the PICU. For approximately 18 hours prior to the scheduled time for tracheal extubation, sedation was transitioned from midazolam and fentanyl to remifentanil. The patient was started on remifentanil at a dose of $0.1 \mu \mathrm{g} / \mathrm{kg} / \mathrm{min}$. Dose adjustments were made in increments of $0.05 \mu \mathrm{g} / \mathrm{kg} / \mathrm{min}$ as needed. An initial infusion dose of $0.2 \mu \mathrm{g} / \mathrm{kg} / \mathrm{min}$ was required to achieve an adequate level of sedation. Dose increases were made twice over the ensuing 9 hours to a maximum dose of $0.3 \mu \mathrm{g} / \mathrm{kg} / \mathrm{min}$. There were no hemodynamic or respiratory adverse effects during the remifentanil infusion. The following day, with both the intensive care unit (ICU) and otorhinolaryngology teams at the bedside, the remifentanil infusion was discontinued. Within 10 minutes, the patient was alert and active with spontaneous eye opening. His trachea was extubated uneventfully, although he subsequently developed moderate stridor and retractions. These were responsive to treatment with racemic epinephrine aerosols, high-flow nasal cannula, and heliox. A nasopharyngeal fiber optic examination at the bedside showed moderate laryngeal edema. The stridor resolved over the next 24 hours and the patient was weaned to room air, after which he was transferred to the inpatient ward and eventually discharged home.

\section{Discussion}

Remifentanil was the last of the current clinically available piperidine, synthetic opioid derivatives, introduced into clinical practice. Its potency and respiratory depressant effects are approximately twice that of fentanyl; however, its clinical half-life is significantly shorter. ${ }^{5,6}$ Its rapid metabolism is the result of the incorporation of a methyl-ester ring into the molecule, which allows for hydrolysis by nonspecific plasma and tissue esterases. Its molecular configuration and rapid metabolism result in a unique pharmacodynamic profile with a rapid onset, easy titration by continuous infusion, and a short context-sensitive half-life with rapid elimination across all age groups regardless of the infusion characteristics. ${ }^{7,8}$ Owing to its predictable characteristics, it has become an effective agent in the neonatal population, allowing the provision of intense analgesia/anesthesia, a rapid recovery profile, and little to no residual effect on respiratory function. ${ }^{9-12}$

Although a frequently used agent for the provision of intraoperative anesthesia, to date, there are limited reports regarding its use for sedation during mechanical ventilation (Table 1). ${ }^{13-21}$ The limited data available demonstrate its efficacy for sedation during mechanical ventilation in the adult, pediatric, and neonatal population with limited adverse physiologic effects. Its sedative effects have been shown to be comparable to those of fentanyl or morphine with a more rapid recovery and weaning from mechanical ventilation. In the patient that we presented, remifentanil provided adequate sedation with rapid dissipation of its effects when the infusion was discontinued to eliminate the potential impact of residual sedation on upper airway and respiratory function in patient with a compromised airway. Further, it allowed for adequate sedation right up to the point of tracheal extubation, minimizing the likelihood of agitation-related airway trauma.

The adverse effect profile of remifentanil is similar to that of other synthetic opioids and includes dose-dependent respiratory depression, bradycardia, and hypotension. Hemodynamic effects are unusual except in the setting of hypovolemia. Furthermore, it should not be used in a patient who has received opioids for a prolonged period of time 
Table I Previous reports of remifentanil use in the intensive care unit population

\begin{tabular}{|c|c|c|c|}
\hline Reference & Demographic data & Remifentanil dosing regimen & Conclusion \\
\hline Breen et $\mathrm{al}^{13}$ & $\begin{array}{l}\text { One hundred and five adult } \\
\text { patients requiring mechanical } \\
\text { ventilation for up to } 10 \text { days. } \\
\text { Medical or postsurgical } \\
\text { comorbidities }\end{array}$ & $\begin{array}{l}\text { Starting dose: } 6-9 \mu \mathrm{g} / \mathrm{kg} / \mathrm{h} \\
\text { Titrate: } \pm 1.5 \mu \mathrm{g} / \mathrm{kg} / \mathrm{h} \text { every } 5-10 \mathrm{~min}\end{array}$ & $\begin{array}{l}\text { Remifentanil reduced the duration of } \\
\text { mechanical ventilation by } 53.5 \text { hours compared } \\
\text { to the control group sedated with midazolam } \\
\text { and fentanyl/morphine. Remifentanil was well } \\
\text { tolerated and administered for up to } 10 \text { days. } \\
\text { The safety profile was thought to be similar } \\
\text { to that of other sedation regimens }\end{array}$ \\
\hline Muellejans et al ${ }^{14}$ & $\begin{array}{l}\text { Eighty adults requiring } \\
\text { mechanical ventilation following } \\
\text { cardiac surgery. Comparison } \\
\text { of remifentanil-propofol vs } \\
\text { midazolam-fentanyl }\end{array}$ & $\begin{array}{l}\text { Starting dose: } 6-12 \mu g / \mathrm{kg} / \mathrm{h} \text { to a } \\
\text { maximum of } 60 \mu \mathrm{g} / \mathrm{kg} / \mathrm{h} \text {. Propofol } \\
0.5-4.0 \mathrm{mg} / \mathrm{kg} / \mathrm{h} \text { if sedation was } \\
\text { inadequate }\end{array}$ & $\begin{array}{l}\text { Remifentanil-based regimen reduced } \\
\text { the time on mechanical ventilation } \\
(20.7 \pm 5.2 \text { vs } 24.2 \pm 7 \text { hours, } P<0.05) \text { and } \\
\text { intensive care unit length of stay }(46.1 \pm 22 \\
\text { vs } 62.4 \pm 27.2 \text { hours, } P<0.05 \text { ) compared to } \\
\text { fentanyl-midazolam }\end{array}$ \\
\hline Akinci et $\mathrm{al}^{15}$ & $\begin{array}{l}\text { Twenty-two children who } \\
\text { required mechanical ventilation } \\
\text { following orthopedic spinal } \\
\text { surgery }\end{array}$ & $\begin{array}{l}\text { Starting dose: } 0.1 \mu \mathrm{g} / \mathrm{kg} / \mathrm{min} \text {. Rate } \\
\text { adjusted up or down by } 25 \% \text { of } \\
\text { starting rate }\end{array}$ & $\begin{array}{l}\text { Remifentanil and fentanyl were comparable } \\
\text { in providing suitable analgesia/sedation } \\
\text { based upon Behavioral Pain Scale and } \\
\text { Riker's Sedation-Agitation Scale. There was } \\
\text { no difference between the two groups in } \\
\text { adverse events }\end{array}$ \\
\hline Welzing et $\mathrm{a}^{16}$ & $\begin{array}{l}\text { Twenty-four mechanically } \\
\text { ventilated infants with a } \\
\text { gestational age }>36 \text { weeks and a } \\
\text { postnatal age }<60 \text { days admitted } \\
\text { to the pediatric intensive care } \\
\text { unit for respiratory failure }\end{array}$ & $\begin{array}{l}\text { Starting dose: } 9 \mu \mathrm{g} / \mathrm{kg} / \mathrm{h} \text {. Titration: } \\
\pm 3 \mu g / \mathrm{kg} / \mathrm{h} \text {. Maximum dose: } 30 \mu \mathrm{g} / \mathrm{kg} / \mathrm{h} \text {. } \\
\text { All patients also received midazolam } \\
50 \mu \mathrm{g} / \mathrm{kg} / \mathrm{h} \text { (maximum dose: } \\
400 \mu \mathrm{g} / \mathrm{kg} / \mathrm{h} \text { ) and were randomized } \\
\text { to remifentanil or fentanyl }\end{array}$ & $\begin{array}{l}\text { Time to tracheal extubation following } \\
\text { discontinuation of the opioid infusion was } \\
\text { shorter: } 80 \text { minutes (IQR I5-165) with } \\
\text { remifentanil compared to fentanyl group: } \\
782 \text { minutes (IQR 250.8-18750) }\end{array}$ \\
\hline Welzing et a $\left.\right|^{17}$ & $\begin{array}{l}\text { Two hundred and forty-three } \\
\text { mechanically ventilated infants } \\
\text { with a gestational age } \\
>36 \text { weeks and a postnatal } \\
\text { age }<60 \text { days admitted to the } \\
\text { pediatric intensive care unit for } \\
\text { respiratory failure }\end{array}$ & $\begin{array}{l}\text { Starting dose: } 9 \mu \mathrm{g} / \mathrm{kg} / \mathrm{h} \text {. Titration: } \\
\pm 3 \mu \mathrm{g} / \mathrm{kg} / \mathrm{h} \text {. Maximum dose: } 30 \mu \mathrm{g} / \mathrm{kg} / \mathrm{h} \\
\text { All patients also received midazolam } \\
50 \mu \mathrm{g} / \mathrm{kg} / \mathrm{h} \text { (maximum dose: } \\
400 \mu \mathrm{g} / \mathrm{kg} / \mathrm{h} \text { ) }\end{array}$ & $\begin{array}{l}\text { Fentanyl group required a } 47 \% \text { increase } \\
\text { in dose compared to } 24 \% \text { increase of the } \\
\text { remifentanil to maintain adequate sedation } \\
\text { levels. Sentence clarification: No opioid } \\
\text { withdrawal noted and patients in both groups } \\
\text { had low average Finnegan scores. }\end{array}$ \\
\hline Giannantonio et al ${ }^{18}$ & $\begin{array}{l}\text { Forty-eight preterm infants born } \\
\text { at } \leq 37 \text { weeks gestational age } \\
\text { requiring mechanical ventilation } \\
\text { for respiratory failure }\end{array}$ & $\begin{array}{l}\text { Starting dose: } 0.075 \mu \mathrm{g} / \mathrm{kg} / \mathrm{min} \\
\text { Maximum dose: } 0.94 \mu \mathrm{g} / \mathrm{kg} / \mathrm{min}\end{array}$ & $\begin{array}{l}97 \% \text { of patients received adequate sedation } \\
\text { and analgesia based upon Neonatal Infant } \\
\text { Pain Scale and COMFORT scores. Time from } \\
\text { discontinuation of remifentanil to extubation } \\
\text { was } 36 \pm 12 \text { minutes. No adverse respiratory } \\
\text { or cardiovascular effects were observed. }\end{array}$ \\
\hline Silva et al ${ }^{19}$ & $\begin{array}{l}\text { Twenty preterm neonates } \\
(28-34 \text { weeks gestational age) } \\
\text { requiring mechanical ventilation } \\
\text { for respiratory distress } \\
\text { syndrome }\end{array}$ & $\begin{array}{l}\text { Starting dose: } 0.5 \mu \mathrm{g} / \mathrm{kg} / \mathrm{min} \text {. Patients } \\
\text { randomized to either morphine or } \\
\text { remifentanil }\end{array}$ & $\begin{array}{l}\text { Both morphine and remifentanil provided } \\
\text { adequate sedation and analgesia based upon } \\
\text { Neonatal Infant Pain Scale and COMFORT } \\
\text { scores. Following opioid discontinuation, } \\
\text { time to infant awakening and tracheal } \\
\text { extubation was } 18.9 \text { and } 12.1 \text { times faster } \\
\text { with remifentanil compared to morphine. }\end{array}$ \\
\hline Cavaliere et $\mathrm{al}^{20}$ & $\begin{array}{l}\text { Ten adults requiring mechanical } \\
\text { ventilation }\end{array}$ & $\begin{array}{l}\text { Starting dose: } 0.02 \mu g / \mathrm{kg} / \mathrm{min} \text {. Infusion } \\
\text { increased to } 0.05,0.10,0.15,0.20 \text {, } \\
\text { and } 0.25 \mu \mathrm{g} / \mathrm{kg} / \mathrm{min} \text { every } 30 \text { minutes. }\end{array}$ & $\begin{array}{l}\text { Infusion rates up to } 0.05 \mu \mathrm{g} / \mathrm{kg} / \mathrm{min} \text { provided } \\
\text { effective sedation. Adverse respiratory and } \\
\text { cardiovascular effects noted at higher doses. }\end{array}$ \\
\hline Dahaba et $\mathrm{al}^{21}$ & $\begin{array}{l}\text { Forty adults requiring } \\
\text { mechanical ventilation }\end{array}$ & $\begin{array}{l}\text { Remifentanil } 0.15 \mu \mathrm{g} / \mathrm{kg} / \mathrm{min} \text { or } \\
\text { morphine } 75 \mu \mathrm{g} / \mathrm{kg} / \mathrm{min}\end{array}$ & $\begin{array}{l}\text { Time in optimal sedation range was higher } \\
\text { in the remifentanil group with less frequent } \\
\text { infusion rate adjustments. The duration of } \\
\text { mechanical ventilation and extubation time } \\
\text { were significantly longer in the morphine } \\
\text { group. More subjects in the morphine group } \\
\text { than in the remifentanil group required } \\
\text { midazolam. The incidence of adverse events } \\
\text { was low and comparable in the two groups }\end{array}$ \\
\hline
\end{tabular}


as the rapid decrease in plasma opioid concentration upon discontinuation may result in withdrawal. A unique effect specific to the synthetic opioids is chest wall and laryngeal rigidity. ${ }^{22,23}$ These effects are related to the dose and rate of administration, and are centrally mediated responses that can interfere with respiratory function. The effect can be reversed with naloxone or interrupted with neuromuscular blocking agents. Although rare, occurrence of chest wall and laryngeal rigidity should be considered if respiratory dysfunction is noted following the administration of synthetic opioids, as such an effect may interfere with respiratory function and result in rapid oxygen desaturation and hypoxemia. To limit the incidence of such issues, a bolus dose should be infused around 2 to 3 minutes as more rapid infusion can cause chest wall rigidity. One other concern with remifentanil is the potential for the rapid development of tachyphylaxis and hence the need to rapidly escalate the dose even during short-term infusions of 24-48 hours. Although suggested in the literature, studies of its use in the ICU for sedation do not uniformly demonstrate this phenomenon. ${ }^{24,25}$ Furthermore, recent animal and retrospective human data have suggested that there may be long-term neurocognitive effects of various sedative agents, including those acting through the $\gamma$-amino butyric acid or $N$-methyl-D-aspartate systems. ${ }^{26}$ Although prospective studies in humans have failed to validate this concern, opioids have not been included in the groups of agents shown to be proapoptotic and responsible for these changes in animal studies.

With these caveats in mind, we believe that the rapid onset and offset of remifentanil may make it a useful agent for the short-term sedation of patients during mechanical ventilation in the ICU setting. The technique may be particularly applicable to various clinical situations where rapid weaning and tracheal extubation are desired, such as the patient with a difficult airway. Given the cost constraints and the potential for tachyphylaxis, we believe that remifentanil should be used only for short-term sedation (48-72 hours) and specific clinical scenarios. In our practice, remifentanil is most commonly used for mechanically ventilated patients who require frequent neurologic assessments due to traumatic brain injury or in patients, such as the subject of this report, with airway concerns for providing a deep sedation and yet allowing for rapid awakening. Our experience would suggest a starting dose of $0.1 \mu \mathrm{g} / \mathrm{kg} / \mathrm{min}$ with increments of $0.05-0.1 \mu \mathrm{g} / \mathrm{kg} / \mathrm{min}$ as needed to achieve the desired depth of sedation. If the patient is already receiving other agents, the remifentanil can be started and then the other agents can be decreased or discontinued.

\section{Disclosure}

The authors declare no conflicts of interest in this work.

\section{References}

1. Tobias JD. Sedation and analgesia in the pediatric intensive care unit. Pediatr Ann. 2005;34(8):636-645.

2. Maxwell LG, Tobias JD, Cravero JP, Malviya S. Adverse effects of sedatives in children. Expert Opin Drug Saf. 2003;2(2):167-194.

3. Bailey JM. Technique for quantifying the duration of intravenous anesthetic effect. Anesthesiology. 1995;83(5):1095-1103.

4. Scholz J, Steinfath M, Schulz M. Clinical pharmacokinetics of alfentanil, fentanyl and sufentanil. An update. Clin Pharmacokinet. 1996; 31(4):275-292.

5. Egan TD, Kern SE, Muir KT, White J. Remifentanil by bolus injection: a safety, pharmacokinetic, pharmacodynamic, and age effect investigation in human volunteers. Br J Anaesth. 2004;92(3):335-343.

6. Glass PS, Gan TJ, Howell S. A review of the pharmacokinetics and pharmacodynamics of remifentanil. Anesth Analg. 1999;89(4 Suppl): S7-S14.

7. Kapila A, Glass PS, Jacobs JR, et al. Measured context-sensitive half-times of remifentanil and alfentanil. Anesthesiology. 1995;83(5): 968-975.

8. Egan TD, Minto CF, Hermann DJ, Barr J, Muir KT, Shafer SL. Remifentanil versus alfentanil. Comparative pharmacokinetics and pharmacodynamics in healthy adult male volunteers. Anesthesiology. 1996;84(4):821-833.

9. Kamata M, Tobias JD. Remifentanil: applications in neonates. J Anesth. 2016;30(3):449-460.

10. Ross AK, Davis PJ, Dear GL, et al. Pharmacokinetics of remifentanil in anesthetized pediatric patients undergoing elective surgery or diagnostic procedures. Anesth Analg. 2001;93(6):1393-1401.

11. Davis PJ, Galinkin J, McGowan FX, et al. A randomized multicenter study of remifentanil compared with halothane in neonates and infants undergoing pyloromyotomy. I. Emergence and recovery profiles. Anesth Analg. 2001;93(6):1380-1386.

12. Galinkin JL, Davis PJ, McGowan FX, et al. A randomized multicenter study of remifentanil compared with halothane in neonates and infants undergoing pyloromyotomy. II. Perioperative breathing patterns in neonates and infants with pyloric stenosis. Anesth Analg. 2001;93(6):1387-1392.

13. Breen D, Karabinis A, Malbrain M, et al. Decreased duration of mechanical ventilation when comparing analgesia-based sedation using remifentanil with standard hypnotic-based sedation for up to 10 days in intensive care unit patients: a randomised trial. Crit Care. 2005;9(3):R200-R210.

14. Muellejans B, Matthey T, Scholpp J, Schill M. Sedation in the intensive care unit with remifentanil/propofol versus midazolam/fentanyl: a randomised, open-label, pharmacoeconomic trial. Crit Care. 2006;10(3):R91.

15. Akinci SD, Kanbak M, Guler A, Aypar U. Remifentanil versus fentanyl for short-term analgesia-based sedation in mechanically ventilated postoperative children. Pediatr Anesth. 2005;15(10):870-878.

16. Welzing L, Oberthuer A, Junghaenel S, Harnischmacher U, Stutzer H, Roth B. Remifentanil/midazolam versus fentanyl/midazolam for analgesia and sedation of mechanically ventilated neonates and young infants: a randomized controlled trial. Intensive Care Med. 2012;38(6):1017-1024.

17. Welzing L, Link F, Junghaenel S, Oberthuer A, Harnischmacher U, Stuetzer H, Roth B. Remifentanil-induced tolerance, withdrawal or hyperalgesia in infants: a randomized controlled trial. RAPIP trial: remifentanil-based analgesia and sedation of paediatric intensive care patients. Neonatology. 2013;104(1):34-41.

18. Giannantonio C, Sammartino M, Valente E, Cota F, Fioretti M, Papacci P. Remifentanil analgosedation in preterm newborns during mechanical ventilation. Acta Paediatr. 2009;98(7):1111-1115.

19. Silva YP, Gomez RS, Marcatto JO, Maximo TA, Barbosa RF, Silva AC. Early awakening and extubation with remifentanil in ventilated premature neonates. Paediatr Anaesth. 2008;18(2):176-183. 
20. Cavaliere F, Antonelli M, Arcangeli A, Conti G, Costa R, Pennisi MA, Proietti R. A low-dose remifentanil infusion is well tolerated for sedation in mechanically ventilated, critically ill patients. Can J Anesth. 2002;49(10):1088-1094.

21. Dahaba AA, Rabner T, Rehak PH, List WF, Metzler H. Remifentanil versus morphine analgesia and sedation for mechanically ventilated critically ill patients. Anesthesiology. 2004;101(3):640-646.

22. Glick C, Evans OB, Parks BR. Muscle rigidity due to fentanyl infusion in the pediatric patient. South Med J. 1996;89(11):1119-1120.
23. Dewhirst E, Naguib A, Tobias JD. Chest wall rigidity in two infants after lowdose fentanyl administration. Pediatr Emerg Care. 2012;28(5):465-258.

24. Vinik HR, Kissin I. Rapid development of tolerance to analgesia during remifentanil infusion in humans. Anesth Analg. 1998;86(6):1307-1311.

25. Guignard B, Bossard AE, Coste C, et al. Acute opioid tolerance: intraoperative remifentanil increases postoperative pain and morphine requirement. Anesthesiology. 2000;93(2):409-417.

26. Blaylock M, Engelhardt T, Bissonnette B. Fundamentals of neuronal apoptosis relevant to pediatric anesthesia. Paediatr Anaesth. 2010;20(5):383-395.
Journal of Pain Research

\section{Publish your work in this journal}

The Journal of Pain Research is an international, peer reviewed, open access, online journal that welcomes laboratory and clinical findings in the fields of pain research and the prevention and management of pain. Original research, reviews, symposium reports, hypothesis formation and commentaries are all considered for publication.

\section{Dovepress}

The manuscript management system is completely online and includes a very quick and fair peer-review system, which is all easy to use. Visit http://www.dovepress.com/testimonials.php to read real quotes from published authors. 